Berislav Majhut

Sanja Lovrić Kralj
UDK: 821.163.42-93.09Pavičić, J.

DOI: http://doi.org/10.21857/ygjwrc625y

Izvorni znanstveni članak

Rukopis prihvaćen za tisak: 20.9.2017.

\title{
JOSIP PAVIČIĆ I SOCREALISTIČKI DJEČJI ROMAN
}

\section{Sažetak}

Vrijeme neposredno nakon 1945. godine rijetko se spominje u povijestima hrvatske dječje književnosti, što je u očitom raskoraku prema važnosti tog razdoblja. Ona se očituje i u revolucionarnoj dinamici zbivanja na tom području i u dalekosežnom postavljanju književnih temelja za daljnji razvoj dječje književnosti u Hrvatskoj.

Odmah nakon rata iskristaliziralo se nekoliko imena koja će predstavljati kanon jugoslavenske dječje književnosti, a iz Hrvatske je jedno od redovito spominjanih imena ono Josipa Pavičića. Razlog tomu nije samo činjenica da je Josip Pavičić pisao naglašeno socijalno angažiranu dječju književnost prije Drugoga svjetskog rata, već on predstavlja jednog od rijetkih, izuzetno aktivnih i plodnih autora, koji su se odmah po završetku rata, što zbog književnog iskustva, izgrađenih stavova ili osobnog vitaliteta, mogli javiti čak i duljim proznim formama.

Trebat će proći određeno vrijeme da se profilira posve nova generacija dječjih pisaca koji sa stvaranjem započinju tek nakon Drugoga svjetskog rata, tako da je u prvim poratnim godinama književna djelatnost počivala na predratnoj gardi dječjih pisaca. Upravo će književni postupci koje Josip Pavičić uvodi u dječji roman i u dječju pripovijetku itekako obilježiti daljnji razvoj obje književne vrste. Ovaj će rad pokušati odrediti na koji je način i do koje mjere Pavičić implementirao socrealistički književni postupak u dječju književnost.

Ključne riječi: socrealistička dječja književnost; socrealistički dječji roman; povijest dječjeg romana; hrvatski dječji roman. 


\section{Josip Pavičić i socrealistički dječji roman ${ }^{1}$}

\section{Hrvatska dječja književnost neposredno nakon 1945.: Prikazi i ocjene}

Onoga tko bi zaželio zadobiti uvid u hrvatsku dječju književnost u godinama neposredno nakon Drugoga svjetskog rata posve sigurno začudila bi brzina i sažetost kojom se u prikazima povijesti hrvatske dječje književnosti to razdoblje prelazi.

U Povijesti hrvatske dječje knjižeonosti: od početaka do 1955. autori Milan Crnković i Dubravka Težak razdoblju nakon 1945. posvećuju tek šest stranica svog opsežnog djela. Procjenjujući književna zbivanja toga razdoblja s estetske točke gledišta, naravno da se o toj književnosti i nema mnogo što reći niti ona može pobuditi išta osim možda želje da je se što prije preskoči i zaboravi.

Malu pozornost navedenom razdoblju posvetit će i Stjepan Hranjec (2006.) navodeći kako književnost koja nastaje u totalitarnim uvjetima s unaprijed određenim ciljevima i zadacima zapravo i nije umjetnost većje ta književnost, kako navodi, „,poslušna, prestrašena i vrlo disciplinirana sluškinja“" (Hranjec, 2006: 90) političkih diktata.

Ibrahim Kajan (2006.) o tom će razdoblju neposredno nakon Drugoga svjetskog rata pisati sa sličnih pozicija te će književnost metaforički nazvati tvorničkom, a književnike manualnim radnicima.

Jedan od najistaknutijih, ili kako će Jelčić (1977.) bolje formulirati „isturenijih“2 književnika toga razdoblja u dječjoj književnosti bit će Josip Pavičić ${ }^{3}$, koji će, uz Matu Lovraka, biti glavno ime novog kanona dječjih pisaca.

O Pavičiću su pisali i teoretičari nedječje književnosti navodeći da on upravo u dječjoj književnosti, kako smatraju zbog njezine didaktičnosti, pronalazi najbolji način

1 Ghrzz Ovaj je rad financirala Hrvatska zaklada za znanost projektom BIBRICH (UIP-2014-09-9823)

2 ,Njegovo ime susretalo se svakodnevno. Često je nastupao na književnim večerima u školama i domovima kulture, kojih je tada bilo u svim većim selima. Njegove pripovijetke čitane su na brojnim subotnjim priredbama u sindikalnim „crvenim kutićima“ naših tvornica i poduzeća ili na gradilištima omladinskih pruga, bez njih obično nisu prolazile ni đačke akademije svakoga prvog svibnja i dvadesetidevetoga studenoga, a malo koja od onih stotina seoskih, radničkih i omladinskih amaterskih kazališnih družina nije tih godina prikazivala njegovu aktovku Veliki krijes, tiskanu u izdanju Nakladnog zavoda Hrvatske odmah poslije rata (1946). K tome je Pavičić bio i jedan od najštampanijih naših pisaca u to doba: za kratko vrijeme od samo nekoliko godina izašlo mu je dvadesetak knjiga, većinom za omladinu." (Jelčić, 1977: 315-316)

3 „Od mladih jedino nešto veću aktivnost pokazuje Danko Oblak, dok su još uvijek najviše čitani i najviše od sebe daju stariji pisci za djecu Mato Lovrak, Josip Pavičić, Sonja Sever i drugi.“ (Ćopić, 1950: 23)

„Interesantno je da je u Hrvatskoj malo mladih pisaca koji se posvećuju i ovom književnom rodu [dječjoj književnosti, op. autori ovog članka], a prirodno je što je do sada tamo bila više negovana proza, valjda zbog toga što je na tom polju put utrveniji posle desetinu vrednih knjiga za decu Pavičića i Lovraka." (Alečković, 1955:378)

„Uz Ćopića, Skendera Kulenovića, Vladimira Nazora, odmah posle rata intenzivno pišu već ranije poznata imena: Mate Lovraka, Desanke Maksimović, Gvida Tartalje, Josipa Pavičića, itd." (Marković, 1958: 72-73) 
prenošenja poruke (usp. Jelčić, 1977., i Sablić, 1994.) jer se čini kako je „primijenjena“ književnost (Jelčić, 1977.) prihvatljiva samo u polju dječje književnosti. Međutim, kada njegov opus procjenjuje estetskim kriterijima, Jelčić umjetničku vrijednost pridaje, kao i Vladimir Popović u predgovoru Pavičićevim djelima u biblioteci Pet stoljeća hrvatske književnosti, samo jednome Pavičićevu djelu, a to je Knjiga o davnini ${ }^{4}$.

\section{Potreba za novom dječjom književnošću}

Prostor posvećen razdoblju neposredno nakon Drugoga svjetskog rata u povijestima hrvatske dječje književnosti u oštrom je raskoraku s teorijskom i povijesnom zanimljivošću tog razdoblja. S teorijske točke gledišta, između ostalih, zanimljivo je pitanje: kako započeti posve novu književnost bez oslonca na povijest dječje književnosti. S povijesne točke gledišta, pak, itekako je zanimljiv početak nove, socijalističke dječje književnosti zbog svoje modelotvorne funkcije.

Nikada prije u hrvatskoj povijesti nije se dogodilo da bi jedna sadašnjost odlučila tako radikalno raskrstiti sa svojom prošlošću kao što je to učinilo društvo nakon 1945. Na području dječje književnosti to je značilo da je vrlo malo, ako išta, iskoristivo iz prošlosti u novoj revolucionarnoj stvarnosti. Jer ako su glavne teme književnosti u prošlosti bile pojedinac i nacija ${ }^{5}$, onda što može ta književnost u situaciji socijalističke revolucije govoriti ljudima koji odbacuju individualizam i privatno vlasništvo uime kolektiva i kolektivnog vlasništva, a s druge strane odbacuju uskost buržujskog koncepta nacije uime kozmopolitskih ideja klasne borbe i oslobođenja proletarijata? Novi društveni stupanj, socijalističko društvo, radikalno je drugačije od svih prethodnih društava u povijesti. Oči onih koji stvaraju novu stvarnost u Jugoslaviji uprte su u iskustva Sovjetskog Saveza, prve i najnaprednije socijalističke zemlje na svijetu.

U našem sovjetskom društvu, u kome su likvidirane antagonističke klase, borba među starim i novim i, prema tome, razvitak od nižeg k višem ne vrši se u obliku borbe antagonističkih klasa i kataklizama, kako je to slučaj

4 „Ako u Pavičićevu književnom djelu ima nekih viših umjetničkih vrijednosti, onda ih smijemo tražiti jedino u Knjizi o davnini [...]" (Jelčić, 1977: 324).

5 Riječi Maksima Gorkog, izvorno objavljene u Sovjetskom Savezu 1933., a otisnute u Jugoslaviji 1945., pružaju smjernice u posve novom području: $u$ dječjoj književnosti, prikladnoj novom revolucionarnom društvu. „U našoj zemlji vaspitati znači revolucionisati, tj. oslobađati mišljenje deteta od t e h n i č k i h navika mišljenja utvrđenih prošlošću, od zabluda u mišljenju, u čijoj je osnovi naslagano mnogovekovno iskustvo konzervativnog života, zasnovanog na klasnoj borbi i težnji jedinki da se zaštite i utvrde individualizam i nacionalizam kao 'večne forme' i zakone socijalnog života.

Vaspitanje dece trebalo bi organizovati tako da se deca od ranog detinjstva, čak i u igrama, odlučno odvajaju od svesne i nesvesne težnje za prošlošću." (Gor'kij, 1945: 11-12) 
u kapitalizmu, nego u obliku kritike i samokritike, koja je prava pokretačka snaga našeg razvitka, moćan instrument u rukama partije. To je apsolutno nov oblik kretanja, nov tip razvitka, nova dijalektička zakonitost. Marx je rekao da su prijašnji filozofi samo tumačili svijet, a da se sada radi o tome da se on izmijeni. Mi smo izmijenili stari svijet i izgradili novi [...] (Ždanov, 1948: 38-39)

Stoga će se i književnost takvog društva radikalno razlikovati od književnosti prethodnih povijesnih razdoblja ili, kako kaže Andrej Aleksandrovič Ždanov:

Kada su feudalni poredak, i poslije, buržoazija u periodi svog procvata mogli da stvore umjetnost i književnost koje su podupirale nastajanje novog poretka i pjevale slavospjeve njegovu procvatu, onda smo mi, novi socijalistički poredak, kao utjelovljenje svega najboljega u historiji ljudske civilizacije i kulture, utoliko prije u stanju da stvorimo najnapredniju književnost na svijetu, koja će ostaviti daleko iza sebe najbolje primjere stvaralaštva starih vremena. (Ždanov, 1946:45-46)

Nova dječja književnost namijenjena djeci novih, socijalističkih generacija treba progovoriti na način koji mora ispuniti revolucionarni zadatak stvaranja novog socijalističkog čovjeka.

\section{Društveno-povijesne okolnosti nakon 1945.}

Izostanak komunističke rigidnosti do izbora za ustavotvornu skupštinu u studenome 1945. vidljiv je, uostalom, i u nastojanju da se tradicija prilagodi novim okolnostima bez radikalnih promjena. Primjerice, $u$ šesnaestome broju ratnog Pionira iz prosinca 1944. na sredini časopisa preko dvije stranice čestita se: „Sretan Božić i Novu godinu najmlađima u Hrvatskoj želi uredništvo ‘Pionira' “. Naglasak je na antifašističkim vrijednostima, još uvijek ne na komunističkima, a list, uostalom, izdaje Glavni odbor Ujedinjenog saveza antifašističke omladine Hrvatske. U Pionirskom kalendaru 1947. objavljenom čak krajem 1946. na zadnjoj stranici u pripovijetki Čekanje Božića još uvijek nalazimo ovakav hibridni opis Božića:

Zdravko izradio iz kartona male srpove, čekiće i kose, presvukao ih srebrnim papirom i pripravio za svoju jelku. Izrezao mnogo petokrakih zvjezdica, obojio ih crvenom bojom, pa će njima nakititi svoje drvce. To će biti drvce radnog naroda - kaže Zdravko pa još više žuri, da dovrši posao. 
Došao je Božić! Drvce je blistalo u žarkim bojama, nitko nije vjerovao, da će tako biti lijepo. Pravo narodno božićno drvce.

- Zar ne mama da i drug Tito, dok je bio mali dječak u Kumrovcu imao je tako lijepo šareno drvce? - pitao je Braco mamu, a mama mu potvrdila i pričala, kako naš narod po selima kiti jeline grane. (Pionirski kalendar 1947., 1946: 64)

Dakle, iako se komunistička vlast stabilizirala 1946. legaliziravši svoju ustavnu poziciju ${ }^{6}$, naslijeđeni običaji još su uvijek živjeli u svakodnevici usprkos traženju načina kako da ih se prilagodi novoj stvarnosti. Tek kad se smogne snaga za radikalni prekid s tradicijom tražit će se uzor u praksama SSSR-a: onako kako su oni prevladali tradicionalne običaje, tako to treba učiniti i u Jugoslaviji. Tek tada će posve nestati Božić, religija će posve nestati iz javnog života, a za one koji se drže tradicionalnih božićnih običaja slijedit će sankcije. Darivanje djece bit će prebačeno na Dan dječje radosti, 31. prosinca, kada će djecu, umjesto malog Isusa, pohoditi Djed Mraz.

Međutim, već 1948. dolazi do razlaza s Informbiroom. Ako ne postoji samo jedan put u komunizam već svaka zemlja mora tražiti svoj put (što je bila glavna teza jugoslavenskih komunista): trebalo je naći korijene komunističke misli i u vlastitoj prošlosti. Otuda nužnost prilagođavanja povijesne slike tridesetih godina aktualnim potrebama Partije na vlasti u smislu predimenzioniranja važnosti Komunističke partije Jugoslavije u društvenim zbivanjima između dva svjetska rata.

Uloga škole $u$ tome je vremenu bila od presudne važnosti za poučavanje novim vrijednostima tek stvorenog društva. Međutim, pedesetih se godina želi uspostaviti i veća kontrola nad slobodnim vremenom djece, pa Centralni komitet Komunističke partije Jugoslavije, nezadovoljan radom Saveza pionira, piše 1950. otvoreno pismo Narodnoj omladini i Savezu komunističke omladine Jugoslavije tražeći reorganizaciju pionirske organizacije (usp. Majhut i Lovrić Kralj, 2016.). Pod izlikom davanja djeci više zabave i igre tražilo se da rukovođenje Savezom pionira preuzmu, umjesto omladinske organizacije, savjeti odraslih, koji bi bolje upravljali izvanškolskim vremenom djece te ga uskladili s radom škole.

6 "Glavna politička borba između snaga starog režima i Narodne fronte pod vodstvom KPJ završila se u razdoblju od oslobođenja zemlje do izbora za konstituantu 11. studenoga 1945. godine." (Bilandžić, 1985: 102)

„Ustavotvorna je skupština 30. siječnja 1946. godine donijela prvi Ustav FNRJ koji je ozakonio sve dotadašnje revolucionarne promjene i dao ustavnu osnovu za dalje provođenje revolucije, prije svega u eksproprijaciji buržoazije i izgradnji državno-socijalističkog društveno-ekonomskog uređenja." (Bilandžić, 1985: 104) 
Nakon 1952. (Krležin govor na ljubljanskom Kongresu književnika) odustaje se od doktrine socijalističkog realizma u umjetničkom stvaranju. U dječjoj književnosti počinje prividno popuštanje ${ }^{7}$ ideološkog pritiska u formi socijalističkog estetizma. Tako se, između ostalog, opet dopušta objavljivanje stripova.

\section{Književne okolnosti nakon 1945. i „čišćenja terena“}

Nakon rata 1945. dio hrvatskih pisaca za djecu završio je na Bleiburgu (Gabrijel Cvitan), križnom putu (Vinko Kos), odveden je iz svog doma bez traga (Zdenka Smrekar), emigrirao je u Južnu Ameriku (Josip Cvrtila) ili je bio prognan iz javnog života poput Štefe Jurkić, Jagode Truhelke, Side Košutić ili Mirka Jurkića.

Prema dopisu od 5. srpnja 1945. dostavljenom iz Društva hrvatskih književnika redakciji tjednika Naprijed, na popisu ${ }^{8}$ književnika za djecu i mladež kojima se dopušta objavljivanje djela u tisku su: Josip Barković, Željko Gumhalter, Joža Horvat, Slavko Kolar, Mato Lovrak, Vladimir Nazor, Josip Pavičić, Nikola Pavić, Jagoda Truhelka i Grigor Vitez (Šarić, 2010: 398-399). Zapravo je osnovni cilj popisa izdvajanje književnika koji su kolaborirali s NDH ili pak naprosto objavljivali tekstove za vrijeme NDH.

Osim pisaca nestalih iz javnog prostora, 1945. su nestale i neke književne vrste koje su tradicionalno pripadale dječjoj književnosti ili su bile dio dječje kulture, kao primjerice trivijalni pustolovni roman. ${ }^{9}$ Nestao je i strip nakon žestokog napada $\mathrm{u}$

$\overline{7}$ Prividnost popuštanja ideološkog pritiska u svim sferama društva bila je refleks prividnog popuštanja na najvišoj razini: „Na šestom kongresu KPJ u Zagrebu od 2. do 7. studenoga 1952. promijenio je ime KPJ u SKJ, i to prema uzoru na Marksovu organizaciju. Ime SKJ zvučalo je više marksistički, a sudionike je uhvatio zanos da se napušta lenjinistički tip monolitne, centralizirane i hijerarhizirane partije koja je bila prepreka demokratskom razvoju. Poručeno je da se napušta vodeća uloga KP i da pod novim imenom preuzima ulogu idejnog usmjeritelja. Šesti kongres KPJ bio je vrhunac pokušaja da se pomire demokracija i socijalizam. Već nakon Staljinove smrti Tito je na Drugom plenumu CK SKJ u lipnju 1953. zaustavio reformu partije." (Radelić, 2006: 293). Milovan Đilas kao najžešći zagovaratelj popuštanja strogosti partijskog nazora (što bi moglo voditi u višestranačje, kao i kritičar bogaćenja partijskih dužnosnika) bio je u siječnju 1954. smijenjen.

8 Popis nije dugačak, a mogao bi biti i kraći: Josip Barković 1945. još nije napisao ništa za djecu, pa ga u tom trenutku možda ni ne treba stavljati na popis književnika za djecu, Joža Horvat napisao je 1939. omladinski roman Sedmi be, a Jagoda Truhelka u vrijeme kada joj komunističke vlasti velikodušno odobravaju književno djelovanje ima 91 godinu.

U članku Danka Oblaka Kako je Vojkan pobijedio Vinetua objavljenom 1947. u Pioniru dječak Vojkan promatra sukob likova iz popularnih djela za djecu koji su pred njima na knjižarskoj polici iznenada postali stvarne osobe: „,- A pustolovina, uzbudljivih istinitih ne možeš dati ti! - razdraženo će 'Sin puka' i stupi s 'Družinom Pere Kvržice' pred Old Šetrhenda. - Vidi ga? Pusto besposleno skitaralo - kakva mu je samo ta puška, prastara lumbarda! A moja mašinka, nova - sedamdeset metaka izbaci odjednom. Pobit ću vas sve ko mačiće! Apaši se uskomešali. Oči su im sijevale ratobornim sjajem." (Oblak, 1947.) U izravnoj borbi likovi trivijalne književnosti (Winnetou) inferiorni su junacima sovjetske dječje književnosti. 
članku u Borbi ${ }^{10}$, gdje je označen kao potrošna roba sa Zapada. ${ }^{11}$ Drastičan su prekid doživjele dječje knjige vjerskoga sadržaja. S polica, a potom i iz sjećanja, nestala je do tada više od stoljeća prisutna priča o Genovevi, a autorima koji su prije Drugoga svjetskog rata pisali u okviru hrvatskoga katoličkog pokreta, poput Štefe Jurkić, bilo je zabranjeno dalje pisati i objavljivati.

Bajke su također doživjele žestoku kritiku, jer što u novoj socijalističkoj stvarnosti imaju raditi kraljevići i princeze? Kakva je bila žestina te kritike, najbolje se vidi u činjenici da su se doslovno desetljećima iza tih kritika vukli repovi. Dovoljno je pogledati priručnik za studente pedagoških akademija iz 1967. Milana Crnkovića Dječja književnost, gdje on obrazlaže argumentima Maksima Gorkog zašto bi ipak trebalo zadržati bajku u dječjem vidokrugu. Jer bajke su izraz narodnog genija. Tako da su, kada je napokon ipak bilo odlučeno da se dopusti objavljivanje bajki, u knjižare stigle uzbekistanske, mongolske, eskimske, hinduske i druge bajke dalekih i egzotičnih naroda, dok će klasične bajke braće Grimm ili Perraulta morati pričekati neka kasnija vremena.

\section{Odgovori književne prakse na zahtjeve društva}

Dobar uvid u produkciju dječje književnosti toga vremena pružaju Viktor Cvitan i Dragutin Franković. Oni su 1947. sastavili Popis izdanja za djecu i omladinu s omotnim naslovom Što da čita moje dijete?. Popis svakako pridonosi razumijevanju poetike dječje književnosti u Hrvatskoj, ali možda ponajviše uvidu u kulturnu politiku toga posebno osjetljivog vremena društvenoga prevrata. Budući da je popis autora kojima je nakon 1945. dozvoljeno stvarati doista malen, a knjižarski prostor potpuno očišćen od prijeratne dekadentne književnosti, taj je prostor nakon 1945. bilo potrebno ispuniti nečime što će biti, prije svega, politički prihvatljivo. Ugledanje u prakse Sovjetskoga Saveza bilo je prokušana receptura i rješenje svakoj nedoumici novoga vremena, pa se tako i u ovom slučaju sovjetska književnost kao ideološki provjerena „roba“ uvozi u relativno prazno područje jugoslavenske dječje književnosti. Nekritički pristup odabiru knjiga koje će se prevoditi,

10 Borba od 5. siječnja 1946. Crnoberzijanska erzac-roba na knjižnom tržištu.

11 Vule, lik iz Oblakove priče, kupio je od svog poznanika staru raskupusanu knjigu sa stripovima. Poslije je Vule ukrao novac ocu da ode u kino, ali je otac to otkrio i suočio sina istini: „-Ti si kriv to je točno. Ali ima još jedan krivac. Evo ga, tu je!“" - reče otac i izvuče iz dječakove torbe knjigu stripova. „-Da nije bilo tih besmislica, ti to sigurno ne bi učinio." „Dugo je još otac razgovarao sa sinom. Pričao mu je o našoj domovini i o teško stečenoj slobodi, o našim trudbenicima, koji s najvećim naporima ispunjavaju naše Petoljetke. Pričao mu je o svojoj tvornici i o svome radu, o tome, kako u našoj industriji treba mnogo novih ljudi. Pričao mu je i o svom djetinjstvu, o životu djece u kapitalističkim državama. Tamo djeca stalno čitaju stripove i mnoga upadaju u prave zločine, jer se tome uče iz stripovske lektire i iz loših filmova." (Oblak, 1949., u Pionir VIII (9): 9) 
od klasika do nekih posve sporednih sovjetskih pisaca, bio je stihijski odgovor na novonastalu situaciju ${ }^{12}$.

Popis je, prema sovjetskome modelu (usp. Balina, 2008: 11), podijeljen na knjige za djecu 3. -7 . godine, za djecu 7. - 9. godine, za djecu 9. $-12 .{ }^{13}$ godine, za omladinu 12. - 15. godine, za omladinu 15. - 18. godine i na Političku knjižeonost za omladinu. Međutim, izdvajanje političke književnosti za posebnu skupinu čitatelja neće značiti da se ona neće namjenjivati i drugim dobnim skupinama čitatelja. Štoviše, pod motom: „Za pravilan fizički razvitak djeteta potrebna je dobra i zdrava hrana. Za pravilan duševni razvitak djeteta potrebna je dobra, napredna dječja knjiga." (Cvitan i Franković, 1947: 5) Autori knjižicu posvećuju roditeljima koji „ispravno shvaćaju golemu ulogu knjige u odgoju djeteta“. Dakle, književnost je ovdje shvaćena isključivo kao sredstvo za pravilan i napredni odgoj. U tom slučaju, djeci je od 7. godine, čim mogu samostalno čitati, potrebno davati pripovijesti o djelima naših, ali i sovjetskih boraca, a kasnije, između ostalog, o Armiji i narodnim herojima.

Iz popisa je uočljivo oslanjanje na sovjetske autore, što se vidi iz činjenice da više od polovice ukupno navedenih naslova pripada sovjetskim autorima (101/196). Međutim, njihova distribucija unutar određenih skupina nije jednaka. Najveći je udio sovjetskih naslova u posljednjoj skupini, namijenjenoj omladini, s omjerom 27/36, te u skupini Političke knjižeonosti za omladinu (12/16). Najprisutniji sovjetski autori su Mihail Il'in sa 6 naslova i Maksim Gor'kij s 5 naslova.

Što se produkcije naslova jugoslavenskih autora tiče, vidljivo je da je najviše naslova (17/33) objavljeno za djecu u dobi 7. - 9. godine, a to je ujedno i razdoblje kada je najmanje sovjetskih naslova uključeno u popis. To nas u konačnici dovodi do zaključka da se nedostatak domaće produkcije popunjava uglavnom prijevodima s ruskog. Prisutnost prijevoda s drugih jezika u ukupnom je broju zapravo zanemariva.

Među preporučenim hrvatskim autorima s najviše su naslova zastupljeni Josip Pavičić (4) i Mato Lovrak (3), dakle autori koji su se još tijekom tridesetih godina 20. st. profilirali kao napredni autori. Međutim, dok se Lovrak preporučuje s naslovima objavljenima još prije rata (Vlak u snijegu, Družba Pere Kvržice i Prijatelji), Pavičić će se pokazati kao naš najaktivniji autor nakon rata. Preporuku su, prema sastavljačima zaslužili naslovi Djeca majke Zemlje (1946.), Slikovnica o životu i svijetu (1946.), Veliki krijes (1946.) i Sjenica (1947.). Od ostalih jugoslavenskih autora najzastupljeniji je Branko Ćopić sa šest naslova.

$\overline{12}$ „U godinama odmah iza Oslobođenja imali smo nerazmjerno velik broj prevedenih stranih djela za djecu, i to gotovo isključivo ruskih: izdavači su tada smatrali, da tu neće pogriješiti u pogledu idejne čistote djela, pa se prevelo i izdalo, pored zaista vrijednih, i dobar broj djela sasvim prosječne, pa i sasvim slabe vrijednosti." (Vitez, 1952: 266)

13 Nisu baš jasni kriteriji kojima su se rukovodili sastavljači popisa jer su se primjerice „stihovi o životu i okolini male djece“ Vlade Babića u Tri ptičice našli u starijoj grupi djece. 
Iz provedene analize proizlazi nekoliko zaključaka. Produkcija dječjih knjiga u Jugoslaviji svoje je središte imala u Beogradu. Tamo su se stihijski i neselektivno odabirali tekstovi sovjetskih autora po načelu ideološke ispravnosti, a novo je vrijeme donijelo i novi žanr političke književnosti za adolescentsku publiku. Oslonac jugoslavenskoj dječjoj knjizi pružili su tek rijetki pisci prošloga razdoblja, što je pokazatelj zazora od svega što u novome vremenu ne bi moglo pronaći svoju primjenu. Svi su stariji tekstovi prolazili dodatna čitanja i provjere kako bi zadovoljili uzuse novoga vremena, pa i sam je Pavičić, primjerice, za izdanje romana Poletarci 1949. godine radio izmjene na romanu izvorno objavljenome 1937.

Prema mišljenju suvremenika, Danka Oblaka, Josip Pavičić najvažnije je ime dječje književnosti u Hrvatskoj. Oblak to obrazlaže ovako:

Poslije oslobođenja imala je naša dječja književnost iza sebe mali broj djela, koja je, u uvjetima novog, mogla pružiti svojim čitaocima. Osim Zmaja Jovana Jovanovića, Vladimira Nazora, Otona Župančića, Ivane Brlić-Mažuranić, Mate Lovraka, Tone Seliškara, Branka Ćopića i Josipa Pavičića teško je bilo naći pisca, čije bi knjige bile prikladne za djecu nove Jugoslavije.[...] Sadržaj je, uglavnom, našla - u Narodnooslobodilačkoj borbi i našoj socijalističkoj stvarnosti. (Oblak, 1950:143)

Kada se to dvoje zbroji i oduzme, onda je vidljivo da Zmaj Jovan Jovanović nije mogao, kao uostalom ni Ivana Brlić-Mažuranić, obrađivati teme iz nedavne prošlosti, Oton Župančić i Vladimir Nazor umrli su 1949. kao sedamdesetogodišnjaci, a Mato Lovrak nije napisao nijednu monografsku knjigu u razdoblju 1945. - 1950. To onda znači da su preostala tri književnika koja su pisala tekstove s temama iz NOB-a i suvremene stvarnosti: Tone Seliškar (1900.), Josip Pavičić (1895.) i Branko Ćopić (1915.). Stoga bez dvojbi Oblak zaključuje: „U Hrvatskoj je poslije oslobođenja na polju dječje literature najpoznatije ime Josipa Pavičića." (Oblak, 1950: 143) Uostalom, to nije samo Oblakovo mišljenje većje, prema mišljenju „struktura“, Pavičićevo stvaralaštvo svjetionik za mlađe pisce, pa je do 1950. Pavičić dobio dvije republičke i jednu saveznu književnu nagradu ${ }^{14}$.

U jugoslavenskoj dječjoj književnosti tog vremena najpopularnija je književna vrsta dječja poezija, a osobito duža narativna pjesma. Tu je veliki uzor Branko Ćopić. U Hrvatskoj stihove za djecu piše Gustav Krklec, i to kratke lirske pjesme (u ciklusima, kao primjerice Cvijeće) te duže narativne pjesme (Pioniri pošumljavajmo), Danko Oblak (Razgovor o Titu) i Josip Pavičić (Slikovnica o životu i svijetu). U pjesmi, u ritmiziranom govoru, lakše je postići da riječi zazvuče poletnije, da riječi pokrenu na

14 Usp. Oblak, 1950: 144. 
akciju, na juriš, da zvuče izazovnije. Tijekom cijeloga prvog desetljeća nakon rata napisano je samo nekoliko dužih proznih djela ${ }^{15}$.

Što se pak proze tiče, osobito dječjih romana - iako su i prije Drugoga svjetskog rata u hrvatskoj dječjoj književnosti postojali romani koji su bili snažno socijalno kritički intonirani - tek će snažno oslanjanje na sovjetsku prijevodnu dječju književnost nakon 1945. stvoriti model socijalističkog realizma ${ }^{16}$.

Ždanov govori o ovim obilježjima književnosti socijalističkog realizma:

1. To je književnost koja radikalno raskida ${ }^{17}$ s buržujskom tradicijom jer građanska tradicija nema što reći novoj socijalističkoj stvarnosti. Socijalističko društvo kvalitativno nadilazi svaku formu građanskog društva koja sva tek moraju završiti u kolapsu i kojima tek predstoji socijalistička faza.

2. To je književnost koja se bavi stvarnošću ${ }^{18}$ ljudi koji žive u najnaprednijoj formi ljudskog društva. To nije književnost koja samo analizira ljudsku stvarnost već je

15 Možemo ih gotovo sve nabrojiti:, Josip Pavičić: Djeca majke zemlje, 1946.; Radost mladog pokoljenja, 1948.; Sonja Sever: Mali Kinez Kong, 1948.; Josip Barković: Sinovi slobode, 1948.; Anđelka Martić: Pirgo, 1953.

16 Dječja književnost ima svoj vlastiti povijesni hod, svoj vlastiti razvoj koji se razlikuje od hoda književnosti za odrasle. Otuda, iz te činjenice, izvlači dječja književnost svoju relativnu autonomnost u odnosu na književnost za odrasle. S druge strane, to onda znači da je, zapravo, nemoguće koristiti pojmove koji su izvedeni iz povijesti odrasle književnosti poput realizma, romantizma, ekspresionizma u teorijskim razmatranjima dječje književnosti. Otkuda onda uopće mogućnost razmatranja „,socrealističkog dječjeg romana"? Ne proturječimo li time sebi kada smo rekli da se pojmovi odrasle književnosti ne mogu primijeniti u dječjoj književnosti (osim na metaforičan način, a mi ovdje ne govorimo na metaforičan način). Odgovor na to pitanje leži u paradigmatskoj slici djeteta toga razdoblja. Predodžba herojskog djeteta (usp. Majhut i Lovrić Kralj, 2016.) nastala u ratnim uvjetima, a zadržana sve do barem 1950., dijete smatra aktivnim, djelotvornim dijelom zajednice u kojoj ono sudjeluje na isti način kao i odrasli. Stoga se i na herojsko dijete odnosi nova agitpropovska funkcija književnosti, pa u književnosti za odrasle i za djecu sličnosti postaju puno veće nego što su razlike.

17 „Neki naši književnici počeli su da smatraju sebe ne učiteljima, nego učenicima buržoasko-malograđanskih literata, počeli su da zauzimaju stav metanisanja i klanjanja pred stranom malograđanskom književnošću. Da li priliči nama, sovjetskim patriotima, takvo metanisanje, nama koji smo izgradili sovjetski poredak, sto puta i viši i bolji od ma kog buržoaskog poretka? Da li priliči našoj naprednoj sovjetskoj književnosti, najrevolucionarnijoj književnosti na svijetu, to metanisanje pred ograničenom malograđansko-buržoaskom književnošću Zapada?" (Ždanov, 1946: 21)

Radikalni razlaz s buržujskom prošlošću vidljiv je i iz riječi Maksima Gorkog na početku knjige Josipa Pavićića Socijalizam našoj djeci: , ,...] prvi put u životu čovječanstva djeca ne predstavljaju nasljednike novca, kuća i namještaja, svojih roditelja, već nasljednike stvarne i moćne vrijednosti - socijalističke države, koju su njihovi očevi i majke stvorili radom. Nikada još djeca nisu stupala u život kao tako svjesni i strogi sudije prošlosti $[\ldots]^{\prime \prime}$.

,[...] Dobroljubov je govorio 'da život ne teče po književnim pravilima, nego se književnost prilagođava pravcima života', i svom snagom je propagirao principe realizma i narodnosti u literaturi, smatrajući da je osnov umjetnosti stvarnost, da je stvarnost izvor stvaralaštva i da umjetnost, formirajući društvenu svijest, ima aktivnu ulogu u društvenom životu. Prema Dobroljubovu, književnost mora služiti društvu, ona mora davati narodu odgovore na najakutnija savremena pitanja, ona mora biti na nivou ideja svoje epohe." (Ždanov, 1946: 29) 
to književnost koja je u stanju mobilizirati i pokrenuti: ona je agitacijska i angažirana u stvaranju stvarnosti.

3. To je književnost koja odgaja ${ }^{19}$ omladinu u duhu borbenosti i želje za izgradnjom socijalističkog društva. Ta književnost prezire dekadentna prenemaganja o umjetničkoj slobodi jer ima mnogo važnija posla: mora aktivno sudjelovati u socijalističkoj revoluciji. Književnost socijalističkog realizma aktivni je činitelj promjena. Jedan od njezinih najvažnijih zadataka jest stvaranje borbene, partijski svjesne omladine, omladine koja će jednog dana biti stanovnik novog svijeta.

4. Toje književnost koja izrasta na temeljima ${ }^{20}$ novog povijesnog iskustva (prve zemlje Sovjeta i Velikog domovinskog rata). U jugoslavenskim uvjetima Narodnooslobodilački je rat antifašistički, ali je u njemu sadržana i socijalistička revolucija.

5. To je književnost s dominantnim i isključivim vrijednostima idejnosti i partijnosti $^{21}$. Znači književnost je u službi Partije, a Partija je avangardni nositelj ideja koje otjelovljuju neizbježni povijesni procesi dijalektičkog materijalizma. Književnost je stoga nužno u službi afirmiranja i aktivnog podupiranja socijalističke klasne revolucije.

Model hrvatskoga dječjeg socrealističkog romana formirali su pisci prijevodne književnosti poput Gajdara (Timura i njegove čete), Kataeva (Sin puka), Ostrovskog (Kako se kalio čelik), Fadeeva (Mlada garda), Boljšincova (Dječak iz Narve), Ul'anove (Lenjinovo djetinjstvo i školske godine) te raznim djelima Čukovski, Il'in i Maršak.

19 „Lenjinizam priznaje našoj književnosti golemo značenje za preobražavanje društva. Kad bi naša sovjetska književnost dozvolila slabljenje te svoje goleme odgojne uloge, to bi značilo nazadak, vraćanje 'kamenom dobu'.

Drug Staljin je nazvao naše pisce inžinjerima ljudskih duša. Ta definicija ima dubok smisao. Ona govori o golemoj odgovornosti sovjetskih pisaca za odgajanje ljudi, za odgajanje sovjetske omladine [...]" (Ždanov, 1946: 32)

20 „Krupan nedostatak u radu naših pisaca također je i udaljavanje od savremene sovjetske tematike, jednostrano zanošenje historijskom tematikom - s jedne strane, a pokušaj obrađivanja čisto zabavnih, praznih sižea- s druge strane.[...] Naš narod očekuje da sovjetski pisci zahvate i uopće ono golemo iskustvo koje je narod stekao u Velikom domovinskom ratu, da prikažu i uopće onaj heroizam s kojim narod danas radi na obnovi narodne privrede zemlje poslije istjerivanja neprijatelja." (Ždanov, 1946: 21-22)

21 Ždanov navodi Lenjinove riječi: „Literatura mora postati partijska. [...] socijalistički proletarijat mora istaći princip partijne literature, razviti taj princip i provesti ga u životu u što punijem i cjelovitijem obliku. [...] U čemu se sastoji taj princip partijne literature? Ne samo u tome što za socijalistički proletarijat literarno djelo ne može biti sredstvo bogaćenja pojedinca ili grupa, nego što ono uopće ne može biti stvar pojedinca, nezavisno od opće proleterske stvari. Dolje van partijski literati! Dolje literati-nadljudi! Književno djelo mora postati dio opće proleterske stvari...« (Ždanov, 1946: 29-30) 
Kao što je već ranije rečeno, prema Cvitan - Frankovićevu popisu dječjih i omladinskih knjiga iz 1947., neposredno nakon 1945. Josip Pavičić pripada grupi najobjavljivanijih autora dječjih knjiga. Pavičić je napisao četiri dječja romana: Poletarce 1937. (1949., 1950., 1980. i 1994.), Djecu majke zemlje 1946., Radost mladog pokoljenja 1948. i Knjigu o davnini 1953. (i 1971.).

Pravi opseg opusa Josipa Pavičića teško je ustanoviti. Ne samo što je vrlo često iste tekstove objavljivao u različitim zbirkama pripovijedaka, već je uključivao i cijele pripovijetke ili dijelove pripovijedaka ili drugih tekstova (igrokaze) u druga djela: Knjigu o davnini objavio je 1953., ali njezine dijelove nalazimo znatno ranije, primjerice već 1946. u Slikovnici o životu i svijetu, gdje opisuje kako je kao dijete koje je tek pošlo u školu crtao na pločici i pokazivao crtež svome djedu. Taj zajednički dio teksta koji se pojavljuje u oba pripovijedanja rabi modularno, pa će priči pridodati rečenicu: „Njega sigurno ne bi primili među pionire, kad ništa ne zna..." (Pavičić, 1946b: 30), rečenicu koju će izostaviti pri uključivanju tog teksta u pripovijedanje Knjige o davnini. Ako ne preuzima doslovno dijelove teksta, onda poseže za likovima i njihovim odnosima (primjerice zidar Tona kao socijalistički agitator među radnicima ciglane, lik djeda ili majke pralje) koje upotrebljava primjerice u igrokazu Stoljetni kalendar, a potom ih prenosi i u Knjigu o davnini.

Budući da je Josip Pavičić najplodniji hrvatski dječji autor u desetljeću nakon 1945., u žarištu našeg zanimanja bit će pitanje je li i, ako jest, u kojoj mjeri Pavičić u svoja djela ugrađivao elemente socijalističkog realizma, dakle poetike čija su djela plavila knjižare u vidu prijevodnih sovjetskih romana, pripovijetki i slikovnica. Kao da se naizgled ponavlja situacija s početaka hrvatske dječje književnosti, kada je prijevodna književnost izgradila očekivanja tadašnje čitateljske publike te time omogućila pojavu hrvatskih autora, samo što sada model socijalističkog realizma ne nastaje spontanim prevođenjima najpopularnijih inozemnih autora već model socijalističkog realizma otjelovljuje zadatke koje je Partija postavila pred književnost i pisce.

Da bismo istražili oslanja li se Pavičić na poetiku socijalističkog realizma, oslonit ćemo se na pet ključnih točaka koje navodi Ždanov (1946.).

Ad. 1. Traži se novi model dječjeg romana - antigrađanski, socijalistički i realistički. Dječji kolektivizam u obliku kako je bio opisan u dječjim romanima prijeratnoga građanskog društva naprosto ne udovoljava novim zahtjevima. Dječje družbe kakve nalazimo u Kästnerovim ili Molnarovim romanima ili, pak, hrvatskim dječjim romanima Heiligsteina i Špoljara samo su čitateljska vježbališta budućih uzornih članova građanskog društva. Pa čak i u Vlaku u snijegu kolektiv nastaje kao školska vježba oponašanja rodovske zajednice. Takav kolektiv koji u romanu služi tome da pojedinac razvije svoju osobnost ne udovoljava zahtjevima socrealističke poetike. Naprotiv, takvom je kolektivu radikalno suprotan kolektiv ocrtan u socrealističkom 
dječjem romanu. Socijalistički kolektiv mora biti povezan s idejom klasne borbe i u službi proleterske revolucije. Primjerice onako kako je to slučaj u Gajdarovu romanu Timur i njegova četa: Timur okuplja grupu od pedesetak djece koja se brine o obiteljima iz kojih su mobilizirani očevi ili sinovi. Kuće ili stanove takvih obitelji Timurovi dječaci označuju crvenom zvijezdom i stavljaju ih pod svoju zaštitu. Dakle, Timur vodi grupu djece koja sudjeluju u ostvarivanju velikoga cilja sovjetskog društva, ali i svih proletera svijeta, u pobjedi proleterske revolucije. Djeca su dio velike ideje koju, u granicama svojih mogućnosti, bezrezervno ostvaruju.

Jednaku predanost ideji imat će i Pavičićevi dječaci u Poletarcima. Naime, kada Rade, lik vođe i idejnog pokretača, shvati da udruženi u kolektiv i malim poslovima koje će odraditi mogu pomoći onima kojima je najteže počinje njihova velika akcija. Podijeljeni u dvije grupe, Radinu i Martinovu, zajednički će pomoći Aniki, čiji je otac ostao bez posla, Jozinoj baki će pripremiti drva za zimu, brinut će se o samoj baki Jagi, Jozi kupiti cipele, a veliki planovi tek slijede završetkom školske godine i osnivanjem nove družbe mlađih članova. Novu će družbu predvoditi Joza, član starijeg kolektiva, čime će se osigurati kontinuitet ideje i nakon što Rade, Martin i Anika odrastu. Uzvišenim tonom i nagovještajem drugačije, bolje, budućnosti roman i završava:

Martine, koliko je to sve skupa?

- Pedeset i pol!

- Toliko! - zadivi se Rade. - Sunce božje, što ćemo mi napraviti ovoga ljeta! Samo dok Joza svoju družinu malo izvježba i pouči... Uh dečki, osvojit ćemo cijeli svijet!

- Zar baš cijeli svijet? - podsmjehne se Tona.

- Da, baš cijeli svijet... Zar ti misliš, da nas na svijetu ima samo pedeset pet i pol? Čekaj malo, kad se svi složimo pa kad narastemo... (Pavičić 1937: 173)

Pavičićev je kolektiv uistinu revolucionaran, sav usmjeren na promjenu društva u kojem su klasne podjele na nas i njih oštro i nepomirljivo povučene. Klasne se opreke ne uspijevaju nadići ni u liku Mihajla, činovničkog sina, koji se, usprkos svojoj velikoj želji za druženjem s ostalim dječacima, ne uspijeva otrgnuti autoritarnome ocu i društvenoj ulozi koja mu je namijenjena. Pavičić klasne opreke naglašava u svakom aspektu dječjih života suprotstavljajući teške uvjete života Anike, Rade i Joze, gladi i nečistoće, s Mihajlovom čistom sobom i vazom s cvijećem na stolu te knjigama i slikovnicama kojima si krati vrijeme. Njihova nejednakost naglašena je i u školi, i to ne samo učiteljevom naklonošću učenicima bogatijih građana nego i prostornim rasporedom: smještanjem radničke djece u zadnje klupe čije su neznanje i nestašluci nerijetko popraćeni fizičkim kažnjavanjem. 
Josip Pavičić 1949. priređuje drugo izdanje svoga romana Poletarci (prvotno objavljenog 1937.) i radi određene izmjene. Upravo je vizija škole nešto čime će Pavičić dopuniti izdanje Poletaraca iz 1949., intervenirajući u radnju romana „naknadnim znanjem“, tj. najavom prave revolucije. Najavit će promjenu slike škole, dolazak nove škole i promjena koje će zahvatiti cijelo društvo. Umjesto u čežnji za promjenom nezadovoljavajućeg stanja, roman iz 1949. završava ushitom zbog vremena koje će doći (a suvremeni ga čitatelj zapravo već živi) čime se naglasak s utopijske slike i društvene kritike društva tridesetih premješta u slavlje novoga vremena koje je u korijenu suprotstavljeno onom davnom mračnom vremenu koje roman prikazuje.

- Čuj, Martine... ala bi to bilo divno, da je naša škola nekako drukčija! I učitelj da ne grdi i ne tuče, da nema gospodske djece i nas u zadnjim klupama, nego smo svi jednaki, kao mi danas u našoj družini. Ej, da mi je ići u takvu školu! Onda bi tek bilo natjecanja, pa i u učenju, a ja sigurno ne bih ostao među najgorima, kao sada... I ne bih nikad zakasnio ni izostao!

- Sunce jarko! Onda bi svaki razred bio kao jedna naša četa, pa da vidiš natjecanja: i jedan s drugim i razred s razredom... Aj, ne smijem ni pomisliti! Da je tako, jednako bih se veselio i školi i školskim praznicima.

- Pričao sam jedamput o tome i Anikinom ocu, -namigne Rade. -Najprije me je začuđeno pogledao, a onda se zadovoljno nasmijao. „Krpiture“, reče mi, „ti si pametniji, nego što bi čovjek rekao na prvi mah, kad te vidi... Kad promisliš, tako bi uistinu trebalo da bude, a tako će sigurno jedamput i biti. Ali dok je „njihova“ vlast, od toga nema ništa...

Kod riječi „njihova“ Rade se obazre na Šestakovu kuću.

(Pavičić, 1949a: 121)

Ad. 2. Realizam pripovijeda stvarnost ${ }^{22}$. Treba odbaciti sva dekadentna i nazadna zastranjivanja građanske umjetnosti predstavljena u raznim -izmima i okrenuti se realizmu ${ }^{23}$. Također, treba se odlučno suprotstaviti svakom književnom eskapizmu.

\footnotetext{
22 Ili, kao što razmišlja Levinson, jedan od junaka Poraza: „[...]razumeo je kakvu ogromnu štetu nanose ljudima izmišljene bajke o lepim pticama - o pticama koje odnekuda treba da izlete i koje mnogi kroz čitav život uzaludno očekuju... Ne, njemu one više nisu potrebne! Nemilosrdno je ugušio u sebi jalovu, slatku tugu za njima - sve što mu je ostalo u nasleđe od ranijih pokolenja. 'Videti sve onakvim kakvo jeste, da bi se izmenilo ono što jeste i upravljalo onim što jeste' - eto do kakve je najprostije i najlakše mudrosti došao Levinson." (Fadeev, 1940: 141)

23 "Na svjetlost dana su se pojavili simbolisti, imažinisti, dekadenti svih boja, koji su se odrekli naroda, koji su proglasili tezu 'umjetnost radi umjetnosti', propovijedali bezidejnost u književnosti [...] Njih je sve ujedinjavao životinjski strah pred bliskom proleterskom revolucijom." (Ždanov, 1946: 12)
} 
Realizam pak ne treba slikati doslovnu aktualnu stvarnost. Ona mora biti viša stvarnost, stvarnost revolucionarne borbe. U zbrkanoj svakidašnjici treba se odbaciti efemerno, a zagrabiti u bitno i živo, ono što je aktualni trenutak revolucionarne borbe. U Fadeevu paradigmatskom socrealističkom romanu Poraz vojnik Mečik u trenutku slabosti otvori srce svome nadređenom Levinsonu i kaže mu kako više ne može izdržati sebičnosti, niskosti i podmetanja suboraca u odredu te da misli kako bi se ti isti njegovi suborci danas-sutra, da ih zarobi njihov neprijatelj Kolčak, s istim žarom borili za njega. Pripovjedač romana međutim ne prenosi sadržaj Levinsonova odgovora već samo kaže kako mu je Levinson odgovorio „uobičajenim rečima“. Mečika to ne razuvjerava i Levinson pomisli kako bi mu zapravo trebao "govoriti o nečemu drugom, osnovnijem i značajnijem, čemu je i sam u svoje vreme prišao sa dosta teškoća i što mu je sada ušlo u telo i krv." (Fadeev, 1940: 139) Socijalistički realizam treba govoriti upravo o tome, o onome što je „ušlo u tijelo i krv“ Levinsona, jednog od junaka romana Poraz. Na samom kraju romana vojnici Mečik i Morozka posve različito reagiraju naletjevši na kozačku zasjedu. Njihove reakcije svedene su na golo instinktivno postupanje, na postupanje koje im nalaže sama srž njihova bića. Mečik misli samo o spašavanju vlastite kože. Naprotiv, Morozka, žrtvujući vlastiti život, upozorava svoj odred na opasnost. U tim reakcijama sadržan je, s jedne strane, malograđanski egoizam, a s druge samožrtvovanje za zajedničku stvar, za veliku zajedničku ideju za koju se bore. I u Morozkinovu postupanju Fadeev nalazi ono što je „ušlo u tijelo i krv“ Morozke i što je posve identično onome što je ušlo u tijelo i krv Levinsona i uostalom svakog od osamnaest preživjelih boraca odreda. To je ono što je sama vitalna snaga Revolucije.

Anonimni pisac pogovora u knjizi Kako se kalio čelik iz 1945. navodi kako je najviši cilj ruskih realista bio stvoriti „,ne kolekciju likova već galeriju tipova ruskog društva“. Nadalje se, pišući o liku revolucionara Rahmetova iz romana Što da se radi? Černiševskog, u pogovoru kaže:

Velika zasluga Černiševskog se sastojala u tome što je opazio tip k o j i s e na zira o u r u skoj st va rn osti. On je opazio onog novog čovjeka koga, uslijed izvjesne ograničenosti svojih pogleda, nisu opazili i nisu mogli duboko i pravilno da shvate ni Turgenjev, ni Gončarov, ni Tolstoj [...]. (379)

I Pavle Korčagin, junak romana Ostrovskog Kako se kalio čelik, predstavlja tip u sovjetskom društvu. Štoviše on nije samo književni tip u kojemu čitatelj prepoznaje određenu grupu ljudi iz sovjetske revolucije ili lik u kojemu čitatelj prepoznaje ljude iz svoje životne okoline. Kod Ostrovskog književni tip postaje sama ideja Revolucije: 
Ne ćemo kazati da svi, ili većina sovjetskih ljudi, imaju Korčaginove osobine. $\mathrm{Ne}$, govori se samo o tome da se Korčaginove osobine sve više šire. Taj pravac razvitka, doista opći pravac, razvijaju kod naroda partija i država. Mnogi bi htjeli da liče na Korčagina, ali svi ne uspjevaju u tome. Korčaginove osobine, to su osobine avangardnoga rukovodećeg dijela na koji se ugledaju mase. (381)

Bio konjanik s puškom na početku romana ili bolesni oslijepjeli mladić na njegovu kraju, Korčaginova vjera, polet i spremnost da sudjeluje u Revoluciji ostaje jednako snažna i neupitna.

U dječjoj književnosti kao da je društvena angažiranost književnosti još dodatno potencirana: agitacija postaje poletnost (nije potrebno navoditi racionalne razloge $\mathrm{e}^{24}$ ni argumentaciju već se u izričaj unosi zajedništvo, poletnost, poziv na juriš).

Upravo je zato u dječjem socrealističkom romanu najvažnija figura gradacija. $\mathrm{Na}$ završnim stranicama Sina puka Vanja Solncev ulazi u vojnu akademiju i zastaje pred slikom na kojoj stari oficir dočekuje u dobrodošlici na vrhu stubišta mladića koji se uspinje stubama prema njemu. Malo kasnije Vanja Solncev sanja kako se on sam nalazi na stubištu kojim se uspinje prema starom oficiru.

Ali odozgor mu je pružio ruku starac u sivom vojničkom plaštu, prebačenom preko ramena, $\mathrm{u}$ visokim cipelama s mamuzama i s dijamantnom zvijezdom na prsima, i sivim uvojkom kose nad prekrasnim naboranim čelom.

Uzeo je Vanju za ruku i poveo ga po stepenicama još više, tamo gdje je na najvišem vrhu medju potrganim ratnim zastavama četiriju pobjedonosnih ratova stajao Staljin s briljantnom maršalskom zvijezdom, koja se svjetlucala i prelijevala ispod njegova šinjela. (Kataev, 1946: 132)

Slika raste od anonimnog dječaka na slici preko vlastitog doživljaja Vanje Solnceva do klimaksa u kojemu Vanja stupa pred samog Staljina.

Sličnim sredstvima služi se obilno i Pavičić opisujući kako je snaga revolucionarne misli u stanju zapaliti i povesti ljude.

Veliki krijes jest „omladinski igrokaz“ prvi put objavljen 1946. (pa potom 1949.). U igrokazu sudjeluju samo dva lika: Marta, 70-godišnja starica, i Ivanka, 12-godišnja učiteljeva kći. Radnja se odigrava u Martinoj sobi u nekom zabitom selu. Marta priča

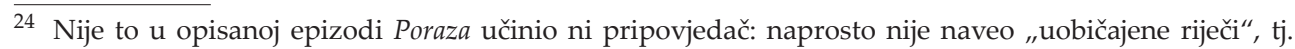
ideološku tiradu kojom Levinson obrazlaže svoje stajalište Mečiku. Dakle, pripovjedač je izostavio eksplicitnu ideološku sekvencu koja je trebala doći na tom mjestu Levinsonovih „uobičajenih riječi”. Umjesto eksplicitnih „,uobičajenih riječi“, radije je pokazano postupanje junaka romana. 
kako je tek nedavno, pod stare dane, naučila čitati. To je sav sadržaj igrokaza. Lik Ivanke tu je naprosto zato da Marta nekome upućuje svoje pripovijedanje.

Cijeli igrokaz potom je gotovo doslovno prenesen $\mathrm{u}$ dječjem romanu Radost mladog pokoljenja (str. 55-60). To jest, prenesene su doslovno Martine riječi, no njih $\mathrm{u}$ romanu izgovara baka Jela. Promijenjena je i situacija: umjesto Marte i Ivanke u Martinoj sobi, kao što je u igrokazu, u romanu se razgovor bake Jele i pionira Anke, Ivanke i Uglješe odvija oko logorske vatre oko koje sjedi velik broj pionira. Marta priča kako je na početku rata gotovo digla ruku na sebe od silnih zvjerstava kojima je nazočila. Ali onda su se u njezinoj kući stali okupljati pioniri iz sela i pioniri-partizani, koji su zajedno čitali, a uz njih se i Marta počela sve više oduševljavati.

Kao da s onih papira ulazi u njih život, kao da se slova pretvaraju u snagu. [...] A riječi teku, plamte režu: doći će kraj paklenoj sili; čovjek će opet postati čovjekom, više nego je to ikad bio, stvorit će se novi život, vredniji, ljudskiji... [...] od snage i vjere promijenila im se lica - nije to više mladež, nego silni, golemi ljudi, kakovih do sada nisam nikada viđala. I razabiram - dat će smjesta život za svaku onu vrelu riječ s papira...(Pavičić, 1949: 16)

[...] tolike vjekove idu ljudi u crkvu, slušajući evanđelje i busajući se u prsa, a poslije opet žive po starom: nanose jedan drugome zlo, nepravdu, izazivaju nesreću... Nema više života u evanđeoskim riječima, one su mrtve, tko bi znao kako već dugo... A, ono što sam ja slušala u onim mrklim noćima - ono je palilo, snažilo, podizalo! Iz toga novog evanđelja ključao je život kao voda iz izvora, buktio kao veliki krijes...(Pavičić, 1949: 17)

Marta ne navodi sadržaj onoga što je slušala već ostaje na vanjskom opisu efekta koji je čitanje imalo na djecu-slušaoce i na nju. Martino pripovijedanje također raste u gradaciji: Ivanka je „upaljena, zanesena“, pa govori „zanosno“, a potom „potreseno". Martine riječi imaju upravo onaj učinak koji se zahtijeva od nove socijalističke književnosti: potresti čitatelja, a onda ga zanijeti i povesti u juriš. Marta pripovijeda kako je sadržaj knjiga pobudio rezonancijom svoje čitatelje (babu Martu i druge) da i oni počinju snažno emotivno reagirati, onda se njihovo uzbuđenje prenosi na Ivanku, a s Ivanke na gledatelje Pavičićeva igrokaza.

U romanu, pak, zbog puno većeg auditorija, prikaz efekta na slušatelje još je jači. Kao da je gledalište ispred kojeg bi se trebao odigrati igrokaz uključeno u pripovijedanje u romanu. Pioniri u romanu kao da zamjenjuju gledalište pred kojim se odigrava Pavičićev igrokaz. „Pioniri su bili tihi kao miševi; oni udaljeniji stadoše se primicati, da bolje čuju."(56); „Pred zanesenim dječjim pogledima..." (57); „U gomili djece nastade uzbuđeno gibanje.“ (58); „Pioniri su sjedili nepomično, nijemi, 
svladani silinom staričinih riječi“ (60); „Visoki, svježi glas izvije prvi napjev, a onda grune čitav zbor: 'Druže Tito...'“(60). Kao da je opis reakcije pionirskog auditorija u romanu svojevrsno pojačalo signala koji ne emitira zvukove već osjećaje entuzijazma i narastanja, ponesenosti i juriša. Gradacija koja dovodi do klimaksa figura je kojom se dječji socroman obilno koristi. Kod Pavičića se taj klimaks redovito manifestira u pjesmi koju likovi zapjevaju o drugu Titu ${ }^{25}$.

Ad. 3. Odgojna, aktivna društvena funkcija književnosti sastavno je obilježje socijalističkog realizma. Takva književnost odgaja borbenu omladinu.

Lenjin je tako velik da ga sestra Ana Ul'anova i u djetinjstvu ne može opisati nikako drugačije nego uspoređujući ga s njime samim (Ul'anova, 1945.). Ona pokazuju Lenjinove negativne osobine. Negativne osobine (toliko je sposoban da možda neće imati priliku izgraditi marljivost (18); ili podrugljivost i zapažanje tuđih mana (17) ne mogu narušiti integritet Lenjinove osobnosti, ali moraju postojati u logici teksta zato da bi ih Lenjin snagom svoje volje mogao svladati i prevladati.

Socijalistički realizam odgaja mlade za novo društvo. To će biti vrsno, kvalitativno drugačiji ljudi od onih prijašnjih. Pavičić u Radosti mladog pokoljenja govori o tom novom društvu koje je već nastupilo!

Baka Jela opisuje vrijeme nakon završetka rata kao posve novo doba u kojemu se promijenila ljudska priroda:

I gle, napokon došlo vrijeme, kad se te riječi ispuniše: narod svladao paklenu silu , uništio dušmanina - i vratila se naša mladost iz šume. Komešam se ja vazdan po selu, među ljudima, radujem se - i strahujem, kako li će se dalje odvijati život. Sve opustjelo, ogoljelo, posvuda razvaline, garišta glad i jad... ali što dalje, u meni počela duša drhtati od radosti. Ljudi postaju drugačiji, srodniji čovječniji - bliži jedan drugome. Nekud nestala njihova prijašnja zla ćud i krv... Zajednički se zlopate, zajednički rade, razumiju svačiju nevolju. Čak i mala djeca - uživaš gledajući, kako se znadu učiti radu i ljubavi. ...(Pavičić, 1948:59)

Govoreći o obilježjima socijalističkog realizma Nemec (2003.) napominje kako uz idealnog, monumentalnog junaka mora ići i stereotipizirani lik negativca. U Radosti mladog pokoljenja uopće nema negativaca. Oni nisu ni tematizirani i dovedeni u obzor pripovijedanja, pa onda ni individualizirani. Negativne sile u društvu ostaju posve amorfne, maknute u stranu i izopćene iz ljudske zajednice.

\footnotetext{
25 Na proplanku str. 106.; Stoljetni kalendar str. 76.; pripovijetka To hoću, to hoću uvijek u Slikovnici o svijetu
} $i$ životu str. 14 . 
Prije se svijet dijelio na gazde i golje, gospodu i sirotinju, a sada svega toga nestalo; po srijedi ostali i zbili se ljudi, drugovi - a po strani se zabrložili neljudi, trag im se zameo, kao što i hoće... (Pavičić, 1948: 59)

Ljudska zajednica naprosto je suštinski promijenjena: ona je sva dobra. Idealizacija socijalističke stvarnosti dobila je, izgonom negativnih sila, svoju dječju apoteozu. I, kako se radi o neposrednoj sadašnjici, socijalistička utopija postala je stvarnost. Ono što je samo naviješteno u Poletarcima kao zanosna budućnost (budućnost koju je naviještao Rade postala je čitateljeva sadašnjost) u Radosti mladog pokoljenja postalo je reporterski zapis o neposrednoj stvarnosti.

Idealiziranje socijalističke stvarnosti postaje jedna od glavnih značajki socijalističkog realizma u dječjoj književnosti. Stvarnost prikazana u književnom djelu već je u skladu s velikim ciljem pobjede socijalističke revolucije. Književno djelo apologija je stvarnosti u kojoj je nastalo. Ono je ne samo na istom smjeru kao i društveni trenutak u kojemu je nastalo već se i vizije djela i društva poklapaju. Stoga je vrlo teško govoriti o socijalističkom realizmu u djelima pisanim u vrijeme prije socijalističke revolucije, u vremenima građanskih društava, zato jer ona neminovno imaju odlike socijalno angažirane književnosti kritički okrenute protiv stvarnosti u kojoj nastaju.

Ad. 4. Socijalistički realizam građu crpi iz prošlosti socijalističke revolucije i Velikog domovinskog, odnosno Narodnooslobodilačkog rata. Međutim, ta je prošlost zapravo živa sadašnjost jer su iste sile djelovale tada kao što djeluju i sada u izgradnji ratom porušene zemlje.

Pripovijetka Dječak iz Narve26 M. Boljšincova priča o osmogodišnjem dječaku koji je 1917. godine otkrio boljševicima mjesto gdje je njegov otac (u tom času u neprijateljskom zarobljeništvu) sakrio puške i tako im omogućio da se naoružaju. Zanimljivo je da se pripovjedač pri tome služi posuđenom varijacijom epizode $u$ Tomu Sawyeru kada dječaci odlaze u ponoć na groblje slijedeći praznovjerje o rješavanju bradavica, pa slučajno postaju svjedoci ubojstva. U pripovijesti Boljšincova, mali Mićka želi noću zakopati ispali zub kako bi mu ostali zubi bili tako čvrsti da može pregristi čavao, pa slučajno postaje očevicem scene u kojoj njegov otac i vojnici skrivaju oružje. U Twainovu romanu ta epizoda služi daljnjem kriminalističkom razvoju radnje. U Boljšincovljevu pripovijedanju, međutim, ta je epizoda presudni kotačić koji je omogućio događaje tog dana, 25. oktobra 1917., koji su pridonijeli pobjedi Velike oktobarske socijalističke revolucije.

$\overline{26}$ Narva, trijumfalna vrata u Sankt-Peterburgu. 
Mićka je heroj koji je bitno utjecao na tijek povijesnih događaja, a s druge strane, na kraju pripovijetke, on je samo jedan od dječaka s Narve, jedan od narodskih dječaka, jedan proleterski dječak.

A kad se pred ulazom na trg Smoljnoga naša kolona zadržala i komandir drugog odreda upitao mornara, pokazujući na mene: »A kakav je to dječak s vama?« onda je moj mornar odgovorio:

„To je valjan dječak... dječak s Narve."

Iako je dječak na početku pripovijedanja jasno imenovan i individualiziran s imenom oca i majke, na kraju pripovijedanja on je samo dio kolektiva (grupe derana koja prati velika povijesna zbivanja), jedan od dječaka s Narve. Ali ono što pripovijedanje čini upravo socrealističkim to je pristajanje uz himnična vihorska, junačka zbivanja, opravdana i neizbježna.

Kod Pavičića nema tema iz narodnooslobodilačke borbe. Teme koje ga zanimaju jesu vlastito djetinjstvo, dakle Požega s početka 20. stoljeća ili pak neposredna sadašnjica, to jest razdoblje „obnove“. Kod Pavičića se gotovo matematički precizno može postaviti formula uspješnosti njegovih dječjih romana. Što se više temelje na njegovim uspomenama, na živom prisjećanju doživljaja iz djetinjstva te opisuju vrijeme kakvo je bilo, to su uspjelija i življa. Naprotiv, u djelima gdje je daleko od svojih uspomena, gdje konstruira i stvara direktno prema potrebama suvremenog trenutka rezultat je krajnje blijed i neuvjerljiv.

Zanimljivo je kako Pavičić teme koje nikako nisu aktualne nego su, dapače, društveno nepoželjne stavlja u Prokrustovu postelju ideologije da bi ih učinio prihvatljivima. U Knjizi o davnini neodoljivo privučen prisjećanjem na djetinjstvo provedeno u Požegi na samom početku 20. stoljeća on pripovijeda dva razdoblja djetinjstva dječaka Paje (očito samog Pavičića): prvo do kretanja u školu, smrti voljenog djeda Martina i zapošljavanja oca kao zvonara u stolnoj crkvi u gradu (sve to u 1901. godini), i drugi dio, tri godine kasnije, kada Pajo već ima deset godina i pomoćnik je ocu, crkvenom zvonaru. Prisjećanje na tijek crkvene godine, službe, običaje, vjernike, svećenike, crkvene sluge, na svoju obitelj zaposlenu oko crkve, prisjećanje na rječnik kojim je jedino moguće opisati Pavičića crkveni svijet neodoljivo umjetnički i životno privlači. Ali to uistinu nije materija koja bi imalo zanimala novo društvo koje se iz petnih žila trudi posve marginalizirati crkvu i po mogućnosti posve neutralizirati njezin utjecaj na socijalističko društvo.

No, da bi svoje uspomene učinio prikladnima za novu stvarnost, Pavičić ih podvrgava ideološkom tretiranju: svi su likovi svećenika i drugih likova vezanih uz crkvu prikazani krajnje negativnim bojama, kao licemjeri i lopovi, a vjernici kao 
ušljivi mahniti luđaci. U toj nakaradnoj crkvenoj sredini prepunoj mržnje, gdje je i sam Bog „zlosutan i pun prijetnje, iz njega izbija neumoljiva okrutnost" (231), posve je moralno prihvatljivo da dječak Pajo krade crkveni novac (jer krade od većih lopova) te da zvonari sa crkvenog zvonika mokre na crkvu (285).

Prvi pak dio knjige, prije očeva zapošljavanja kao zvonara, dakle dok je još bio postolar, uglavnom se bavi imperijalizmom, kapitalizmom i eksploatacijom radnika.

Ambijent, likove i njihove odnose iz prvog dijela Knjige o davnini Pavičić je već ranije preliminarno obradio u igrokazu Stoljetni kalendar. Prve tri slike igrokaza odigravaju se na samom početku 20 st., a četvrta slika 50 godina kasnije. U prvoj slici Božo i Jura, četrnaestogodišnjaci i silno neuka i zapuštena djeca, odluče zaraditi čestitajući ljudima, ali ne kao sva ostala djeca Novu godinu, već Novo stoljeće. Zamole svoga prijatelja Gruju da im sastavi čestitku. Grujo se međutim odluči našaliti, pa im napiše čestitku u kojoj će oni zaželjeti da se sve staro sruši, a da se proleteri ujedine, pa im predloži da tom čestitkom obraduju građane. U drugoj se slici Božo i Jura nađu u jednom gradskom dvorištu, gdje skriveni čuju priznanje vlasnika trgovine cipelama Baloga da je pred bankrotom. U trećoj slici zidar Tona objašnjava Boži i Juri kako bi se sigurno, samo da su im građani uopće dopustili dokraja izrecitirati čestitku, loše proveli. Grujo se dobro našalio s njima. Tona ih upućuje da nikada više ne traže napojnice od građana već da se drže svojeg društvenog sloja. Klase moraju biti nepomirljive i radikalno suprotstavljene, a proleteri moraju čekati odlučnu borbu spremni i dobro organizirani. Pedeset godina kasnije sve je potpuno drugačije: „Teku dani novog vijeka,/ raste prva petoljetka/ pod okriljem moćnog štita /Partije i Tita!“ (Pavičić, 1950., 76) a Božo i Jura prekaljeni su komunistički rukovodioci.

Najvažniji oslonac socrealističkome romanu jest revolucija sama po sebi, pa će tako analitičari sovjetske književnosti naglašavati nemogućnost postojanja istinske socijalističke književnosti prije Oktobarske revolucije (Balina i Rudova, 2008.). U našim bi prilikama to značilo da socrealizam ne može postojati prije 1945. Vidljivo je to i iz nekih odlika socrealističkog romana poput naglašavanja partijnosti dihotomijom nazadnog nekoć i naprednog sada. U Poletarcima je ta dihotomija nemoguća jer će dihotomija, s obzirom na to da je radnja smještena prije revolucije, glasiti: nezadovoljavajuća sadašnjost i utopijska budućnost. Tek intervencijama koje je Pavičić učinio 1949. ovaj se roman približava idealima socrealističkog romana, ali nažalost, tada gubi na životnosti i onim najneposrednijim izletima u sjećanja iz djetinjstva. Kako bi postigao snažnu klasnu suprotstavljenost, iskoristit će crno-bijelu karakterizaciju likova tako što će redom izbaciti sva ona mjesta u kojima siromašni stanovnici Ciglarske ulice žive u nečistim uvjetima isprepletenima smradom fekalija, prijenosnih spolnih bolesti, alkoholne ovisnosti i maloljetničke spolnosti. Ono što će 1949. željeti naglasiti jest nespojivost i nepomirljivost klasa te nagovještaj smjene "njihove“ građanske vlasti „našom“ proleterskom. 
Ad. 5. Partijnost. Neovisno kojim se sadržajem književno djelo bavilo, ono uvijek mora biti viđeno s točke gledišta partijskih ciljeva, a to će reći s pozicije klasne borbe:

Upravo to da svaki pisac pišući svoje delo posmatra život sa određenog stajališta, da su osnovne crte njegovog pogleda na svet, koje su odredile to stajalište, determisane društvenom sredinom, da je prema tome to stajalište klasnog karaktera i da delo znači učešće pisca u klasnoj borbi, upravo to i znači partijnost književnog stvaranja. (Latković, 1950: 9)

U svakom trenutku književne povijesti zna se tko je napredan autor, a tko nazadan. A u vrijeme socijalističke revolucije tko je revolucionar, a tko reakcionar.

To da se svaka povijesna i društvena pojava može gledati kao napredna ili reakcionarna, sa stajališta onodobnih društvenih odnosa, u dječjoj književnosti zadobila je ponešto drugačiju formu. U dječjem svijetu, u kojemu povijest ne znači puno jer ni osobne povijesti nema mnogo, ta prožetost povijesti općom idejom klasne borbe zadobila je formu svijeta u kojemu sva bića i sve stvari glasno zagovaraju stranu pravedne borbe.

Jedna od omiljenih pjesničkih figura jest personifikacija. U Ćopićevim Pričama partizankama iz 1945. u prvoj priči Ustanak na Krajini personificirane su planine i gradovi Grmeč, Kozara i Drvar. Dakle, nisu se samo ljudi dignuli na ustanak već i nežive stvari sudjeluju u borbi. Goleme geografske pojave ${ }^{27}$ nisu neutralni teren na kojemu se sukobljavaju ljudi već su i same stale na stranu pravedne borbe. Cijeli svijet, sve što postoji, od stvari preko životinja do ideja, sve se to idejno svrstalo na naprednu stranu. U priči iz iste zbirke Priča o roguljama personificirani su alati, pa rogulje (vile) pričaju kako su ustašama i Nijemcima otimale mitraljeze i topove. U priči Ko dobija bitke prepire se oružje koje je najzaslužnije za dobivene bitke. U Priči o heroju i krvavoj kuli razgovaraju krvava kula, tisućugodišnji hrast i vrabac o divovskoj snazi heroja Tita. U uvodu Ćopićeve zbirke same su priče personificirane jer su bića koja prolaze kroz razne ratne nevolje: jedna se nedovršena „gola i bosa" morala povlačiti pred neprijateljem, a druga je priča bila opkoljena od Švaba na Šator-planini, pa se morala probijati iz obruča itd. Cijeli svijet stavljen je u jedan pokret, $\mathrm{u}$ jedno gibanje $\mathrm{s}$ jednim ciljem i jednom svrhom: pravedne proleterske borbe. Ako su pokrenuti ne samo ljudi, već i sva živa bića i sve nežive stvari, i

\footnotetext{
27 Slično kao u pathetic phalacy, gdje se, osobito u romantizmu, duševna zbivanja u likovima projiciraju na prirodne pojave, pa je ljubavna katastrofa projicirana na goleme atmosferske pojave na oluje, vihore, gromove i munje, tako ovdje ljudska zbivanja zahvaćaju stvari i velike prirodne pojave kao što su planine, rijeke, predjeli.
} 
cijeli svijet giba se u samo jednom smjeru, onda se to kretanje ne može podvrgnuti ikakvom propitivanju.

Sličnom pripovjednom strategijom u kojoj životinje služe za prijenos ideološki ispravnih misli o prirodi i čovjeku koristi se i Pavičić. Roman Djeca majke zemlje prati život mladog šišmiša od rođenja pa do kraja prve godine života. U središtu je zanimanja odnos malog šišmiša i „čovječića“. Paralelizam njihovih naravi, eksplicitan u izjavi majke-šišmiša: „Ovaj moj čovječić uvijek je dobar, nasmijan i radoznao, kao mali šišmiš... Da ima krila, bio bi sasvim sličan tebi!" (22) podcrtan je i njihovim životnim i društvenim prilikama: mali šišmiš živi sa svojom majkom jednako kao što čovječić-dječak živi sa svojom majkom - očeva nigdje na vidiku. Odnos majke i njihovih mladih u različitim vrstama samo je odraz fundamentalnog odnosa izraženog u naslovu romana: djeca majke zemlje. Vrhovna vrijednost o kojoj govori roman jest život u svim svojim manifestacijama (62).

Dječak-junak zaštitnik je noćnih životinja: starog ćuka koji živi na vrhu zvonika i dvoje šišmiša. Tako dječak hrani i njeguje starog ćuka koji već dvije godine ne može poletjeti, a jednom prilikom dječak spasi mladog šišmiša kojega je susjed pribio na ulazna vrata da mu donese sreću.

Dječak je zvonar, a njegova funkcija upozoravanje na vrijeme ${ }^{28}$, međutim nigdje u tekstu ni traga crvenoj službi zvonara ni crkvi. Ono što navodi ljude na zlo jest praznovjerje, pa će tako praznovjerje biti i motiv susjedu da pribije šišmiša na svoja kućna vrata. Životinje, stari ćuk i majka-šišmiš, poučavaju malog šišmiša o životu, o bićima koja nastanjuju svijet i prije svega o čovjeku koji je najveća tajna. Jer čovjek je gospodar svijeta:

Na svijetu ima mnogo većih i jačih životinja od čovjeka, a ipak on im je svima gospodar; one ili ga se boje ili mu služe. I ne samo to - sve na svijetu podvrgavao je on pod svoju vlast: zemlju, vodu, zrak, šume, polja... ama sve! Ne mogu dokučiti, odakle njemu ta snaga! (27)

[...] ta oni su gospodari svijetla [sic!] pa mogu pretvoriti dan u noć [sic!]; znadu hvatati munju i grom... Sve je to djelo njihovog uma, mozga - i ruku, koje slušaju taj um. (27)

[...] Mi, drugi stvorovi, živimo sami za sebe, pojedince ili u manjim jatima i čoporima. Čovjek ne - on je sav jedna zajednica. Tu je izvor one snage, a kojom on osvaja i preobrazuje svijet. Jedan um s dvije ruke može učiniti mnogo, ali snaga bezbrojnih složnih umova i ruku je neizmjerna. [...] Naš, životinjski um sasvim je drukčiji; on ne gleda u budućnost, mi živimo

28 „Zvono javlja ljudima, da je noć pri kraju; valja im napustiti ležaj, počinje danji život, buka, nemir, rad... Ljudi će ustati i raditi sve do mraka..." (23) 
i mislimo samo za danas. Čovjeku to nije dosta... on traži i osjeća sreću u neprekidnom zajedničkom umovanju i radu, ali ne samo za danas, nego i za daleku budućnost... (28)

Dakle, karakteristično je za socrealizam uvođenje budućnosti kao najvažnije dimenzije vremena. No ta budućnost neće se pojaviti ako ne postoji sadašnjost $u$ kojoj se potrebno žrtvovati da bi se budućnost mogla materijalizirati.

Pavičićeva knjiga namijenjena je čitateljima u ranoj dječjoj dobi, onima kojima će prisnost s majkom biti prije neposredna potreba nego iskustvo. Cvitan i Franković uvrstili su je u štivo za publiku u dobi 9 - 12 godina, iako je očito da bi mogla prije zanimati djecu od 9 negoli od 12 godina. Knjiga kao da je priprema za materijalističku nadogradnju socijalističkog čovjeka i eksplikacija nastavnog plana u nižim razredima osnovne škole ${ }^{29}$. Sličnu funkciju obavlja i Slikovnica o svijetu i životu iz 1946.

" - Kako, ti ne znaš, što je fašizam? - uskipi mati. - A već ti je skoro šest godina!“ (Pavičić, 1946b: 24)

Dijete ima već šest godina, a još ne zna što je fašizam. Krajnje je vrijeme da nauči. Slikovnica će tu postati ozbiljni udžbenik.

\section{Zaključak}

Za razliku od mnogih drugih hrvatskih pisaca koji su pisali prije Drugoga svjetskog rata, Josip Pavičić placet za objavljivanje dobio je odmah nakon 1945., i to zahvaljujući reputaciji koju je stekao svojim već objavljenim djelima. Očekivanja koja su u njega polagale partijske strukture zadužene za književnost nakon Drugoga svjetskog rata Pavičić je već od prvih svojih pripovijedanja namijenjenih djeci potpuno opravdao. Zato je Pavičić, tada najistaknutiji dječji autor, vrlo brzo ušao u novi kanon jugoslavenske dječje književnosti.

\footnotetext{
29 „Upoznavanje prirode i društva.

Zadatak je nastave ovoga predmeta:

- da omogući učenicima pravilno shvaćanje zbivanja u prirodi, t. j. da shvate prirodu kao proces, u kojemu je sve podvrgnuto kretanju, promjenama i usavršavanju;

- da omogući učenicima da shvate uzroke osnovnih prirodnih pojava, snagu ljudskog uma i rada, kojima čovjek prodire u stanja prirode i pokorava prirodne sile, postaje gospodar prirode i svojih vlastitih društvenih odnosa;

- da se kod učenika usvajanjem pravilnog gledanja na prirodna i društvena zbivanja suzbije i oteža mogućnost prodiranja praznovjerja i predrasuda, koje mladu generaciju okružuju;

- da se učenici upoznaju s ulogom, pravima i dužnostima radnog čovjeka u socijalističkoj zajednici;

- da u njima razvija ljubav prema radu i poštivanje prava i sloboda čovjeka[...]“ (26)
} 
Komunistička književna kritika nakon rata postavila je normativni zahtjev „,da se književnost podredi aktualnoj politici revolucionarnog vremena kako bi djelovala kao agitaciono sredstvo na marksističkoj ideološkoj liniji“ (Marković, 1958: 73). Na taj društveni zahtjev, međutim, trebalo je odgovoriti konkretnim književnim djelima. U nedostatku dovoljnog broja djela jugoslavenskih književnika za djecu posegnulo se za obilnim prevođenjem sovjetske književnosti koje je stvorilo model jugoslavenskoga dječjeg romana socijalističkog realizma.

Slijedeći razvojnu liniju zacrtanu već tridesetih godina, u svojim socijalnokritičkim i socijalno angažiranim dječjim pripovjednim djelima Pavičić je nakon Drugoga svjetskog rata smjesta prigrlio zasade socijalističkog realizma. Dapače, prihvatio ih je toliko usrdno, pa ne samo što je neka djela nastala ranije "poboljšao" revidirajući ih u novom duhu (primjerice Poletarce iz 1937.), već je i kasnija djela čija se tema opirala socrealističkom pristupu nemilosrdno flagelantskom strogošću sapeo u tražene okvire (prije svega to vrijedi za Knjigu o davnini).

Pavičić je u svojim romanima usvojio zacrtani model slijedeći ga u svim glavnim crtama: snažna protugrađanska crta koja izbija iz naglašavanja kolektivizma nasuprot sebičnom individualizmu, jako protureligijsko osjećanje; realistički prosede u naglašeno promidžbenom ključu, apoteoza socijalističke stvarnosti; odgojna uloga književnosti u stvaranju omladinaca i djece za novi svijet; veličanje iskustava izgradnje zemlje i idealizacija socijalističke stvarnosti te, nakraju, partijnost i idejnost koja se nameće sadržaju pripovijedanja mogao to on podnijeti ili ne.

Jedna od dviju najznačajnijih osobitosti Pavičićeva stvaralaštva jest traženje inspiracije u vlastitom djetinjstvu. Ono čime Pavičićeve najbolje stranice privlače čitatelja jest njegova neodoljiva potreba da se vrati vlastitom djetinjstvu kao izvoru svakog nadahnuća. A Pavičićevo djetinjstvo njegovo je djetinjstvo u Požegi. On u svojim romanima nigdje izravno ne imenuje Požegu već govori o provincijskom gradiću ili sl., ali zato se s nasladom prisjeća i opisuje stare požeške vedute. Zato privlačnost Pavičićeva stvaralaštva, usprkos često teško probavljivoj ideološkoj isključivosti, leži u prizivanju i neprestanom vraćanju u svoje djetinjstvo, a to znači Požegu, i to Požegu iz vrlo uskog povijesnog horizonta prvih godina 20. stoljeća. Što je invokacija djetinjstva dalja i slabija, to je i djelo artificijelnije i neuspjelije (primjerice, udaljeno prisjećanje na dane zvonarenja u Djeci majke zemlje rezultirat će mlakim neuvjerljivim djelom, a smještanje radnje Radosti mladog pokoljenja u selo pokraj Karlovca rezultirati njegovim daleko najneuspjelijim djelom).

Najbolje stranice njegova romana Poletarci upravo su one na kojima je inkorporirao slike iz djetinjstva. Ma koliko radnja bila artificijelno iskombinirana da bi mogla poduprti ideološku strukturu romana, to ne može uništiti zanimljivost romana. Nažalost, slično se ne može reći za romane napisane nakon 1945. ni za verziju Poletaraca iz 1949. 
S druge strane, pritisak da se piše u ključu socijalističkog realizma kod Pavičića je toliko jak da je posve prevladao stranu naturalistički oslikanoga djetinjstva u Knjizi o davnini, njegovu nesumnjivo najambicioznijem pripovjednom djelu. Smisao za nalaženje onog bitnog realističkog detalja koji je svojom sugestivnošću u stanju obojiti cijelu prikazanu fresku kod Pavičića je iznimna. Ali onda uvijek i neminovno dolazi ideološka obrada freske i odjednom cijeli oživljeni prizor posve gubi vjerodostojnost. Uspomene na njegovo djetinjstvo koje je proveo pomažući ocu u poslovima crkvenog zvonara postaju povod najžešćeg napada na crkvu i vjeru. Taj napad ne predstavlja nikakvo slobodno autorsko uvjerenje već način kako da se tema vlastitog djetinjstva provedenog u službi Crkve učini prihvatljivim u povijesnom trenutku radikalnog komunističkog obračuna s Crkvom, kad je se nastoji na svaki način ne samo marginalizirati već i posve isključiti iz socijalističkog društva. Pavičić disciplinirano slijedi ideološku zapovijed vremena da se Crkva diskreditira i svaki i najmanji detalj knjige upravljen je u tom smjeru. Partijnost i idejnost glavne su odlike pripovijedanja u Knjizi o davnini.

Josip Pavičić prvi je hrvatski književnik koji je pisao dječje socijalističke realističke romane. U jugoslavenskim prilikama za razlaz s doktrinom socijalističkog realizma obično se uzima 1952. i Krležin govor na Kongresu pisaca u Ljubljani. No, silnice socrealizma i dalje su bile jake, pogotovo u dječjoj književnosti, gdje do 1953. praktično još nemamo ni dječji ratni roman (ako Barkovićeve Sinove slobode iz 1948. označimo kao roman za mladež).

Godina 1953. godina je dramatičnih zbivanja: Tršćanska kriza, Staljinova smrt, nastanak prve hidrogenske bombe. U hrvatskoj dječjoj književnosti Josip Pavičić objavljuje 1953. svoj posljednji dječji roman, Knjigu o davnini. Pavičić je, iako nedvojbeno pripada starijoj generaciji književnika, najagilniji i najplodniji hrvatski pisac za djecu u prvom desetljeću nakon Drugoga svjetskog rata. On kao da te 1953. godine predaje štafetu dječjeg romana Anđelki Martić, spisateljici generacije stasale nakon Drugoga svjetskog rata, koja te godine objavljuje prvi hrvatski ratni dječji roman Pirgo.

\section{Literatura}

\section{Primarna:}

Boljšincov, Manuelj (1957), Dječak s Narve. Zagreb: Mladost.

Ćopić, Branko (1945), Priče partizanke. Zagreb: Prosvjeta.

Fadeev [Fadejev], Aleksandr Aleksandrovič (1940), Poraz: roman. Beograd: Nolit.

Gajdar, Arkadij (1963), Timur i njegova četa; Komandant snježne tvrđave. Zagreb: Mladost.

Kataev [Katajev], Valentin (1946), Sin puka: pripovijest. Zagreb: Vjesnik. 
Oblak, Danko (1947), Kako je Vojkan pobijedio Vinetua. Pionir VI (19), str 11-13.

Oblak, Danko (1949), Priča o Vuletu, gorljivom čitaču stripova, Pionir VIII (8), str. 6-8 i Pionir VII (9), str.9-10.

Ostrovskij, Nikolaj Alekseevič (1945), Kako se kalio čelik, Zagreb: [Naprijed]

Pavičić, Josip (1937), Poletarci. Zagreb: Konzorcij

Pavičić, Josip (1946a), Djeca majke zemlje: pripovijest za omladinu. Zagreb: Omladinski nakladni zavod.

Pavičić, Josip (1946b), Slikovnica o svijetu i životu. Zagreb: Nakladni zavod Hrvatske.

Pavičić, Josip (1948), Radost mladog pokoljenja: romantična omladinska kronika. Zagreb i Beograd: Novo pokoljenje.

Pavičić, Josip (1949a), Poletarci. Zagreb i Beograd: Novo pokoljenje.

Pavičić, Josip (1949b) Veliki krijes; Senkin izvor. Zagreb: Novo pokoljenje.

Pavičić, Josip (1950), Stoljetni kalendar; Na proplanku. Zagreb: Novo pokoljenje.

Pavičić, Josip (1959) Što pričaju dan i noć. Zagreb: Matica hrvatska.

Pavičić, Josip (1971), Izabrana djela: Knjiga o davnini. U: Pet stoljeća hrvatske književnosti, Zagreb: Zora i Matica hrvatska.

Ul'anova, [Uljanova] A. I. (1945), Lenjinovo djetinjstvo i školske godine. Zagreb: Nakladni zavod Hrvatske.

\section{Sekundarna:}

Balina, Marina (2008), Creativity through Restraint: The Beginnings of Soviet Children's Literature. U: M. Balina i L. Rudova (ur.), Russian Children's Literature and Culture. New York i London: Routledge.

Bilandžić, Dušan (1985), Historija socijalističke federativne republike Jugoslavije: glavni procesi 1918-1985. Zagreb: Školska knjiga.

Clark, Katerina (2001), Socialist Realism in Soviet Literature. U: N. Cornwell (ur.) The Routledge Companion to Russian Literature. New York i London: Routledge.

Crnković, Milan (1967) Dječja književnost: priručnik za studente pedagoških akademija i nastavnike. Zagreb: Školska knjiga.

Crnković, Milan i Dubravka Težak (2002), Povijest hrvatske dječje književnosti od početaka do 1955. Zagreb: Znanje.

Cvitan, Viktor i Dragutin Franković (1947), Popis izdanja za djecu i omladinu [omotni naslov: Što da čita moje dijete?]. Zagreb: Nakladni zavod Hrvatske.

Ćopić, Branko (1950), Naša dečja književnost. Nastava jezika i književnosti u srednjoj školi: časopis za stručna i metodska pitanja, I (1-2), str. 20-28. 
Gor'kij, [Gorki] Maksim, A. Beljajev i V. Tauber (1945), Dajte djeci literaturu!. Beograd: Novo pokolenje.

Hranjec, Stjepan (2006), Pregled hrvatske dječje književnosti. Zagreb: Školska knjiga.

Jelčić, Dubravko (1977), Josip Pavičić. U: Vallis aurea: eseji i portreti. Zagreb: Matica hrvatska, str. 313-330.

Kajan, Ibrahim (2006), Grubići i nježnići: eseji iz hrvatske i studija iz bh. dječje književnosti. Zagreb: Sabor bošnjačkih asocijacija Hrvatske.

Latković, V. (1950), Partijnost književnog stvaranja. U: Nastava jezika i književnosti u srednjoj školi 1 (1-2), str.7-14.

Majhut, Berislav i Sanja Lovrić Kralj (2016), Slika djeteta u dječjoj književnosti pedesetih godina 20. stoljeća u socijalističkoj Jugoslaviji: dijete-heroj. Detinjstvo 42 (2), str. 43-53.

Marković, Slobodan (1958), Književnost za decu nastala između dva svetska rata na srpskohrvatskom jezičnom području. U: Književnost za decu i rad u dečjim bibliotekama: zbornik materijala sa seminara za rad u dečjim bibliotekama. Beograd: Savet društva za staranje o deci i omladini Jugoslavije.

Nemec, Krešimir (2003), Povijest hrvatskog romana: od 1945. do 2000. godine, Zagreb: Školska knjiga.

Oblak, Danko (1950), O dječjoj literaturi Josipa Pavičića. Izvor 3 (2), str. 143-146.

Radelić, Zdenko (2006), Hrvatska u Jugoslaviji 1945.- 1991.: od zajedništva do razlaza, Zagreb: Hrvatski institut za povijest i Školska knjiga.

Šarić, Tatjana (2010), Djelovanje Agitpropa prema književnom radu i izdavaštvu u NRH, 1945-1952. Radovi - Zavod za hrvatsku povijest, 42, str. 387-424.

Vitez, Grigor (1952), Neki problemi naše savremene književnosti za djecu. Pedagoški $\operatorname{rad} 7$ (7), str. 257-267.

Ždanov, Andrej Aleksandrovič (1946), Referat o časopisima »Zvijezda« $i$ »enjingrad«, Beograd i Zagreb: Kultura.

Ždanov, Andrej Aleksandrovič (1948), Riječ u diskusiji o knjizi G. F. Aleksandrova »Historija zapadnoevropske filozofije«(24. juna 1947.), Beograd i Zagreb: Kultura. 


\section{Josip Pavičić and the Social Realist Children's Novel}

\section{Summary}

The period immediately following 1945 is rarely mentioned in the anthologies of Croatian children's literature; this stands in discrepancy with the importance of this period.

Immediately after World War II, several authors, who were to become representatives of the canon of Yugoslav children's literature, stood out. Among Croatian authors, Josip Pavičić was almost regularly mentioned. The reason for this lies not only in the fact that in the period prior to World War II, Pavičić wrote socially engaged literature, but also in the fact that in the period immediately following the war, Pavičić was an exceptionally active and prolific author, who, owing to his literary experience, developed attitudes and personal vitality, and was thus able to publish more extensive works. In this period, there were not many such authors.

A certain period of time had to pass before a completely new generation of children's writers, who started writing after the war, came out of age. In the first years of the aftermath, literary activity in Croatia still relied on pre-war children's writers. The literary procedures that Pavičić introduced into the children's novel and children's story were the ones that exercised a strong influence on the further development of both genres. The objective of this work is to examine in which ways and to which extent Pavičić implemented the social realist literary procedure into children's literature.

Keywords: social realist children's literature; social realist children's novel; history of children's novel; Croatian children's novel.

Izv. prof. dr. sc. Berislav Majhut

Učiteljski fakultet Sveučilišta u Zagrebu

Odsjek u Petrinji

Savska cesta 77, 10000 Zagreb

berislav.majhut@ufzg.hr

Doc. dr. sc. Sanja Lovrić Kralj

Učiteljski fakultet Sveučilišta u Zagrebu

Odsjek u Petrinji

Savska cesta 77, 10000 Zagreb

sanja.lovric@ufzg.hr 